\title{
ANALISIS KESALAHAN PENULISAN BERDASARKAN PUEBI PADA KARYA TULIS ILMIAH MAHASISWA PRODI PETERNAKAN FAKULTASPERTANIAN UNIVERSITAS VICTORY SORONG
}

\author{
La Ode Madina ${ }^{1}$ \\ Universitas Victory Sorong \\ laodemadinanoken@gmail.com \\ Alfonsina Mlik ${ }^{2}$ \\ alfonsinamlik@gmail.com \\ Novita Asmuruf ${ }^{3}$ \\ Novitaasmuruf0@gmail.com
}

\begin{abstract}
ABSTRAK
Penulisan karya ilmiah tentunya mempunyai keterkaitan dengan penerapan kaidah ejaan.Ejaan merupakan pedoman umum yang di dalam mengatur tentang hal ihwal penulisan huruf, satuan bahasa, unsur serapan, serta tanda baca.Dalam kenyataannya penulisan karya ilmiah khususnya skripsi mahasiswa banyak ditemukan kesalahan-kesalahan berbahasa yang diantaranya kesalahan penggunaan huruf, penulisan kata, unsure serapan, atau bahkan penggunaan tanda baca.oleh karena itu mengacuh pada Permendikbud No. 50/2015 tentang Pedoman Umum Ejaan Bahasa Indonesia yang merupakan bentuk penyempurnaan atas ejaanejaan sebelumnya. Terkait dengan hal itu perlunya dilakukan penelitian tentang penerapan ejaan bahasa Indonesia.Adapun tujuan dari penelitian ini untuk mendeskripsikan penerapan Pedoman Umum Ejaan Bahasa Indonesia pada skripsi Mahasiswa Prodi Peternakan.Jenis penelitian ini adalah penelitian kualitatif yang menggunakan metode deskripsi dan metode pustaka.Data dalam penelitian ini adalah keseluruhan teks yang terdapat pada Skripsis Mahasiswa Prodi Peternakan Universitas Victory Sorong.Berdasarkan hasil penelitian ditemukan kesalahan pemakaian pemakaian huruf, huruf kapital dan huruf miring berjumlah 105 kesalahan, Kesalahan penulisan kata yang meliputi kata dasar, kata turunan, kata ganti, kata depan, singkatan dan akronim berjumlah 88, dan kesalahan pemakaian tanda baca berjumlah 62 kasus kesalahan.
\end{abstract}

Kata kunci: kesalahan penulisan, karya ilmiah, prodi peternakan.

\section{ABSTRACT}

Writing scientific papers certainly has a relationship with the application of spelling rules. Spelling is a general guideline that regulates the writing of letters, language units, absorption elements, and punctuation marks. In fact, in writing scientific papers, especially student thesis, many language errors are found, including errors in the use of letters, writing words, absorption elements, or even the use of punctuation marks therefore referring to Permendikbud No. 50/2015 concerning General Guidelines for Indonesian Spelling, which is a form of improvement over the previous spellings. In this regard, it is necessary to conduct research on the application of Indonesian spelling. The purpose of this study is to describe the application of the General Guidelines for Indonesian Spelling in the thesis of Animal Husbandry Study Program students. This type of research is a qualitative research that uses 


\section{JURNAL J-MACE}

Vol.1, No. 1, Juli 2021, hlm. 26-40

the method of description and the method of literature. The data in this study is the entire text contained in the Student Thesis of Animal Husbandry Study Program, Victory University, Sorong. Based on the results of the study, it was found that there were 105 errors in the use of letters, capital letters and italics, word writing errors which included basic words, derivative words, pronouns, prepositions, abbreviations and acronyms totaled 88 , and punctuation errors totaled 62 cases of errors.

Keywords: writing error, scientific work, animal husbandry study program. 


\section{PENDAHULUAN}

Penggunaan bahasa yang benar menurut pedoman umum ejaan bahasa Indonesia (Puebi) merupakan salah satu faktor yang sangat penting dalam hal tulis-menulis. Peubi merupakan hal yang sangat penting dalam penyusunan sebuah tulisan ilmiah.Tulisan ilmiah harus didasari dengan penulisan yang benar mengikuti aturan Ejaan yang sudah diatur dan ditetapkan. Namun pada kenyataannya, masih banyak kesalahan pada penggunaan ejaan.Masalah ejaan tampakanya sangat sederhana namun kesederhanannya itulah yang sering dilupakan oleh penulisnya. Padahal Puebi, kamus, dan tatabahasa merupakan ramburambu untuk menuliskan bahasa tulis baku. Ketepatan penggunaan ejaan yang sesuai dengan Puebi bisa dijadikan ukuran pemahaman bahasa seseorang. Persoalan ejaan bukanlah sesuatu yang sulit, karena bila seorang menguasainya cara menuliskan kata, kalimat dengan baik, bahkan penempatan tanda baca dengan sesuai, kemungkinan orang tersebut tidak akan membuat kesalahan.

Dalam hal ini, penulis menemukan beragam kesalahan yang dapat ditemukan dalam Skripsi Mahasiswa Prodi Peternakan pada Fakultas Pertanian, Universitas Victory Sorong menjadi salah satu pembuktian bahwa masih banyak ditemukan kesalahan dalam penggunaan bahasa terutama dalam hal ejaan dalam menulis sebuah skripsi. Padahal mahasiswa dituntut untuk menerapkan ejaan yang benar sesuai dengan kaidah karena melalui kegiatan menulis tugas akhir skripsi mahasiswa dilatih untuk terampil menerapkan aspek kebahasaan, seperti kosa kata, tata bahasa, ejaan, dan tata bunyi.

Kesalahan ejaan termasuk salah satu jenis kesalahan berbahasa dalam bahasa tulis.Hal itu sangat mempengaruhi kualitas sebuah tulisan.Suatu tulisan yang sudah sempurna menurut segi isi belum tentu dapat dikatakan tulisan yang baik. Apabila banyak kesalahan ejaan dan tanpa memperhatikan ejaan yang benar, isi tulisan tidak dapat disampaikan kepada pembaca secara jelas dan tepat. Oleh karena itu, penelitian ini dilakukan untuk mengetahui tingkat kesalahan ejaan dalam skripsi mahasiswa prodi peternakan Fakultas Pertanian, Universitas Victory Sorong. Selain itu, akan diketahui secara rinci bagaiman tingkat ejaan yang benar dalam skripsi mahasiswa Prodi Peternakan Fakultas Pertanian Universitas Victory Sorong sehingga akan diketahui kemampuan mahasiswa dalam kegiatan menulis skripsi dengan ejaan yang benar.

Dengan demikain, Rumusan dalam penelitia adaalah Bagaimana bentuk kesalahan penulisan huruf, kesalahan penulisan kata, kesalahan penulisan unsur serapan, dan bentuk kesalahan penempatan tanda baca yang terdapat pada Skripsi mahasiswa Prodi Peternakan Fakultas Pertanian Universitas Victory Sorong?. Tujuan penelitian ini mendeskripsikan kesalahan penulisan huruf, kesalahan penulisan kata, kesalahan penulisan unsur serapan, kesalahan penempatan tanda baca pada Skripsi Mahasiswa Prodi Peternakan Fakultas Pertanian Universitas Victory Sorong. 


\section{KAJIAN TEORI}

\section{A. Pengertian Puebi}

Pada tahun 2016 berdasarkan Keputusan Menteri Pendidikan dan Kebudayaan, Dr. Anis Baswedan, Pedoman Umum Ejaan Bahasa Indonesia yang Disempurnakan (PUEYD) diganti dengan nama Pedoman Umum Ejaan Bahasa Indonesia (PUEBI) yang penyempurnaan naskahnya disusun oleh Pusat Pengembangan dan Pelindungan, Badan Pengembangan dan Pembinaan Bahasa.

\section{B. Ruang Lingkup Pedoman Umum Ejaan Bahasa Indonesia}

Pedoman Umum Ejaan Bahasa Indonesia di dalammya meliputi

\section{Pemakaian Huruf}
a. Huruf abjad
f. Huruf capital
b. Huruf vokal
g. Huruf miring
c. Huruf konsonan
h. Huruf tebal
d. Huruf diftong
e. Gabungan huruf konsonan

2. Penulisan kata
a. Kata dasar
g. Partikel
b. Kata berimbuhan
h. Singkatan dan akronim
c. Bentuk ulang
i. Angka dan bilangan
d. Gabungan kata
j. Kata ganti
e. Pemenggalan kata
k. Kata sandang
f. Kata depan

\section{Pemakaian Tanda Baca}
a. Tanda titik
b. Tanda koma
c. Tanda titik koma
d. Tanda titik dua
e. Tanda hubung
f. Tanda pisah
g. Tanda Tanya
n. Tanda penyingkat

h. Tanda seru

i. Tanda ellipsis

j. Tanda petik tunggal

k. Tanda kurung

1. Tanda kurung siku

m. Tanda garis miring

\section{Pengertian Skripsi}

Menurut KBBI skripsi adalah karangan ilmiah yang wajib ditulis oleh mahasiswa sebagai bagian dari persyaratan akhir pendidikan akademisnya. Skripsi adalah bagian dari suatu karangan (fakta) jenis karangan khususnya mengenai suatu topic keilmiahan dan pada umumnya ditujuhkan pada siding pembaca yang berkincimpung dalam bidang pengetahuan ilmiah yang bersangkutan (P. westra:1991). 


\section{METODE PENELITIAN}

\section{A. Jenis Penelitian}

Penelitian ini merupakan penelitian kualitatif yang termasuk dalam penelitian kebahasaan. Boy dan Taylor (Moleong, 2006:4) mengatakan bahwa kualitatif merupakan prosedur penelitian yang menghasilkan data deskriptif berupa kata-kata tertulis atau lisan dari orang-orang dan perilaku yang dapat diamati.

\section{B. Tempat dan Waktu Penelitian}

\section{Tempat Penelitian}

Tempat penelitian tidak terikat pada suatu tempat karena objek yang dikaji berupa naskah atau teks berita yang terdapat dalam skripsis mahasiswa prodi pertanian Unvic Sorong tahun 2013 dan 2014.

\section{Waktu Penelitian}

Penelitian ini dilaksanakan sejak penulis dinyatakan layak melakukan penelitian berdasarkan keputusan tim.

\section{Sumber Data}

Sumber data dalam penelitian ini berupa data tertulis yang terdapat pada Skripsis Mahasiswa Prodi Pertanian Fakultas Peternakan Universitas Victory Sorong Tahun 2013 dan 2014.

\section{Teknik Pengumpulan Data}

Teknik pengumpulan data dalam penelitian ini menggunakan teknik baca selanjutnya yang dilakukan dalam penelitian ini adalah teknik catat.Taknik catat ini digunakan untuk mengungkapkan suatu permasalahan yang terdapat dalam suatu bacaan atau wacana (Sudaryanto, 1999: 41).

\section{E. Teknik Analisis Data}

Analisis data merupakan upaya peneliti menagani langsung masalah yang terkandung dalam data (Sudaryanto, 2001: 3-6).Dalam tahap ini untuk memperoleh deskripsi bentuk kesalahan ejaan digunakan metode padan dan agih (distribusional). Metode padan digunakan untuk menganalisis sekaligus menafsirkan peristiwa-peristiwa berbahasa yang berkaitan dengan faktor penentuan penggunaan bahasa yang alat penentunya berupa bahasa tulis. 


\section{HASIL DAN PEMBAHASAN}

\section{A. Hasil}

Hasil penelitian yang disajikan adalah jenis kesalahan ejaannya, yaitu pemakaian huruf, penulisan kata, penulisan unsur serapan, dan pemakaian tanda baca.

Tabel 2 Persentasi Kesalahan Ejaan Pada Skripsi Mahasiswa Prodi

\begin{tabular}{|l|l|l|l|}
\hline No & Aspek Kesalahan Ejaan & Frekuensi & Persentase \\
\hline 1 & Penggunaan huruf, huruf kapital & 105 & $41.17 \%$ \\
\hline 2. & Penulisan tanda baca & 88 & $34.52 \%$ \\
\hline 3 & Penulisan kata & 62 & $24.31 \%$ \\
\hline \multicolumn{2}{|c|}{ Jumlah } & 255 & $100 \%$ \\
\hline
\end{tabular}

\section{B. Pembahasan}

Pembahasan ini didasarkan atas kesalahan ejaan. Adapun pembahasan hasil penelitian tersebut adalah sebagai berikut.

\section{Kesalahan Pemakaian huruf (Skripsis, S.B 2014)}

1."Metode pemeliharaan ini memiliki risiko terinfeksi oleh berbagai penyakit parasit salah satu diantaranya adalah penyakit cacing pada mata" hlm 3

2."Menurut damayanti (2009) menyatakan bahwa penyakit cacing thelazia jarang meransang reaksi pandangan." hlm 8

\section{Pembenaran}

1."Metode pemeliharaan ini memiliki resiko terinfeksi oleh berbagai penyakit parasit salah satu diantaranya adalah penyakit cacing pada mata." hlm.3

2. "Menurut damayanti (2009) menyatakan bahwa penyakit cacing thelazia jarang merangsang reaksi pandangan." hlm.8

\section{Kesalahan Penggunaan Huruf (Skripsis. O.G 2013)}

1. "Penyelesaian kendala yang ada dalam menjalankan system peternakan sapi potong di daerah penelitian." hlm 5

2. "Sinkronisasidaerah pengembangan agribisnis peternakan dengan komoditas lain." hlm8

3. "Keberhasilan usaha ternak sapi bergantung pada tiga unsur yaitu bibit, pakan, dan manajemen atau pengelolaan." hlm 9

4. "Manfaat dari ternak sapi potong selain dagingnya kotoran ternak sapi berypa pupuk kandang sangat diperlukan untuk tanaman pertanian penduduk." hlm10

\section{Pembenaran}

1. Penyelesaian kendala yang ada dalam menjalankan sistem peternakan sapi potong di daerah penelitian.

2. Sinkronisasidaerah pengembangan agrobisnis peternakan dengan komoditas lain. 
3. Keberhasilan usaha ternak sapi bergantung pada tiga unsur yaitu bibit, pakan, dan manajemen atau pengelolahan.

4. Manfaat dari ternak sapi potong selain dagingnya kotoran ternak sapi berupa pupuk kandang sangat diperlukan untuk tanaman pertanian penduduk.

\section{Kesalahan penggunaan huruf(Skripsis. A.B.2014)}

1. "Kepuasan pelanggan perlu disurvey." hlm 10

2. "Dengan adanya ladang pengembalaan lebih mempermudah masyarakat setempat untuk memeliharah ternak sapinya." Hlm15

\section{Pembenaran}

1. Kepuasan pelanggan perlu disurvei.

2. Dengan adanya ladang pengembalaan lebih mempermudah masyarakat setempat untuk memelihara ternak sapinya.

\section{Kesalahan penggunaan huruf (Skripsis.P.S.2014)}

1. "Peternakan kambing potong di kabupaten sorong merupakan usaha yang dapat meningkatkan pendapatan peternak dan keluarganya sehingga layak untu di usahakan." hlm 5

2. "Kambing kacang merupakan hewan pememah biak berkuku genap dan hampir semuanya merupakan hewan pegunungan yang suka hidup dilereng-lereng curam.’hlm 7

\section{Pembenaran}

1.Peternakan kambing potong di kabupaten sorong merupakan usaha yang dapat meningkatkan pendapatan peternak dan keluarganya sehingga layak untuk di usahakan.

2.Kambing kacang merupakan hewan pemamah biakkan berkuku genap dan hampir semuanya merupakan hewan pegunungan yang suka hidup dilereng-lereng curam.

\section{Kesalahan penggunaan huruf kapital (Skripsis, S. B. 2014)}

1.Hipotesis yang dikemukakan mendahului penelitian ini adalah pencegahan terhadap penyakit cacing khususnya Penyakit cacing Thelaziadi Distrik Klamono Kabupaten Sorong.Skripsi A.2014.Hal 4)

2.Thelaziosis merupakan Suatu Penyakit cacing mata yang disebabkan oleh Thelazia spp. (Skripsi A. 2014. Hal 5)

3.Siklus hidup Thelazia spp. adalah tidak langsung yaitu memerlukan induk semang antara lalat Musca larvipara dan Muxca confexifronts. (Skripsi A. 2014. Hal 5)

4.Gejala Klinis terlihat adanya lakrimasi, kemerahan dan pembekakan konjungtiva, photophobia dan beberapa kasus terjadi keratitis dan keadaan melanjut dapat terjadi kebutaan. (Skripsi A. 2014. Hal 5)

5. A. Tempat Dan Waktu Penelitian (Skripsi A. 2014. Hal 5) 
6. Bahan Dan Alat (Skripsi A. 2014. Hal 5)

\section{Pembenaran}

1. Hipotesis yang dikemukakan mendahului penelitian ini adalah pencegahan terhadap penyakit cacing khususnya penyakit cacing Thelaziadi Distrik Klamono Kabupaten Sorong.

2. Thelaziosis merupakan suatu penyakit cacing mata yang disebabkan oleh Thelazia spp.

3. Siklus hidup Thelazia spp. adalah tidak langsung yaitu memerlukan induk semang antara lalat musca larvipara dan muxca confexifronts.

4. Gejala klinis terlihat adanya lakrimasi, kemerahan dan pembekakan konjungtiva, photophobia dan beberapa kasus terjadi keratitis dan keadaan melanjut dapat terjadi kebutaan.

5. A. Tempat dan Waktu Penelitian

6. Bahan dan Alat

\section{Kesalahan Penggunaan Huruf Kapital (Skripsis. O. G. 2013)}

1. Atau mencampurkannya dengan tanaman leguminosa seperti Gamal, Kaliandra, Turi, Lamtoro, Siranto yang memiliki gisi tinggi. (Skripsi B. 2013. Hal : 19)

2. Kuisioner yang dibagikan Ke Responden (Skripsi B. 2013. Hal:24)

3. Sampel diambil sebanyak $10 \%$ dari jumlah populasi dengan menggunakan teknik Random Sampling. (Skripsi B. 2013. Hal:28)

\section{Pembenaran}

1. Atau mencampurkannya dengan tanaman leguminosa seperti gamal, kaliandra, turi, lamtoro, siranto yang memiliki gisi tinggi.

2. Kuisioner yang dibagikan ke Responden

3. Sampel diambil sebanyak $10 \%$ dari jumlah populasi dengan menggunakan teknik random sampling.

Kesalahan penggunaan huruf capital (Skripsis. A.B. 2014)

1.Populasi Ternak Kambing Potong Menurut Distrik Di Kabupaten Sorong Tahun 2013. (Skripsi C. 2014. Hal : 2)

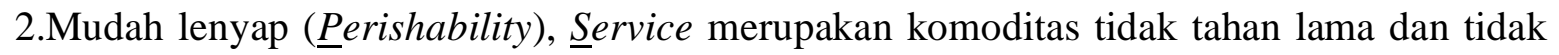
dapat disimpan. (Skripsi C. 2014. Hal : 5)

\section{Pembenaran}

1. Populasi ternak kambing potong menurut distrik di Kabupaten Sorong Tahun 2013.

2. Mudah lenyap perishability, service merupakan komoditas tidak tahan lama dan tidak dapat disimpan. 


\section{Kesalahan Penggunaan Huruf Kapital (Skripsis. P.S.2014)}

1. ternak kambing merupakan salah satu ternak penghasil daging yang cukup banyak permintaannya. (Skripsi D. 2013. Hal:1)

2. Bagaimana pola pengolahan usaha peternakan kambing potong yang dilakukan oleh Masyarakat di Kabupaten Sorong.

(Skripsi D. 2013. Hal:4)

3. Alat yang di gunakan dalam penelitian ini adalah alat tulis, Kalkolator, $\underline{\mathrm{HP}}$, Komputer. (Skripsi D. 2013. Hal:14)

\section{Pembenaran}

1. Ternak kambing merupakan salah satu ternak penghasil daging yang cukup banyak permintaannya.

2. Bagaimana pola pengolahan usaha peternakan kambing potong yang dilakukan oleh masyarakat di Kabupaten Sorong.

3. Alat yang di gunakan dalam penelitian ini adalah alat tulis, kalkolator, hp, komputer.

\section{Kesalahan penggunaan huruf kapital pada Skripsis.Petrus Samagita.2014.Prodi Peternakan.}

1. Menurut Sriwahyuni, (2009) Biogas merupakan salah satu dari banyak macam sumber energi terbarukan, karena energy biogas dapat diperoleh dari air buangan rumah tangga, kotoran, .....(Skripsi E. 2013. Hal:2)

2. Bertolak dari permasalahan diatas, maka penulis tertarik untuk melakukan penelitian mengenai pemanfaatan limbah kotoran ternak untuk biogas di kelurahan klasaman Kota Sorong yang mana dapat membantu petani peternak dalam pemanfaatan limbah kotoran ternak.....(Skripsi E. 2013. Hal:4)

3. Kelurahan Klasaman adalah salah satu di wilayah distrik sorong timur berada kurang lebih $12 \underline{\mathrm{Km}}$ dari pusat pemerintahan kota sorong dengan luas wilayah kurang lebih 12,5 km2 dengan batas wilayah: (Skripsi E. 2013. Hal:25)

\section{Pembenaran}

1. Menurut Sriwahyuni, (2009) biogas merupakan salah satu dari banyak macam sumber energi terbarukan, karena energi biogas dapat diperoleh dari air buangan rumah tangga, kotoran, ......

2. Bertolak dari permasalahan diatas, maka penulis tertarik untuk melakukan penelitian mengenai pemanfaatan limbah kotoran ternak untuk biogas di Kelurahan Klasaman Kota Sorong yang mana dapat membantu petani peternak dalam pemanfaatan limbah kotoran ternak..... 
3. Kelurahan Klasaman adalah salah satu di wilayah Distrik sorong timur berada kurang lebih $12 \mathrm{~km}$ dari pusat pemerintahan Kota Sorong dengan luas wilayah kurang lebih $12,5 \mathrm{~km} 2$ dengan batas wilayah

\section{Penggunaan Tanda Baca}

Berikut ini data yang menunjukkan kesalahan ejaan yang disebabkan oleh penggunaan tanda baca titik.

\section{Kesalahan penggunaan tanda titik pada Skripsi. S.B. 2014)}

1. ...bagaimana cara mencegah, menanggulangi dan mengobati penyakit Thelasia pada sapi di Distrik Klamono Kabupaten Sorong [tidak ada tanda titik]

2. Pengembangan usaha peternakan dari kepentingan masyarakat pada umumnya. di Distrik Klamono Kabupaten Sorong[tidak ada tanda titik] (Skripsi A. 2014. Hal:5)

3. Thelasiosis merupakan suatu penyakit cacing mata yang disebabkan oleh Thelasia spp. dan dapat menyerang berbagai jenis ternak. Thelasia spp. yang benyak menyerang ternak sapi adalah ... (Skripsi A. 2014. Hal:5)

4. Diagnosa didasarkan atas ditemukan cacing Thelasia sp. pada kantung konjungtif dengan jalan membuka kedua kelopak mata. (Skripsi A. 2014. Hal:5)

5. Pencegahan dilakukan penyemprotan secara teratur untuk membatasi factor penyebab penyakit ini[tidak ada tanda titik](Skripsi A. 2014. Hal:5)

6. ....secara berkala setiap 3-4 bulan sekali guna membasmi cacing secara tuntas dan memutus siklus hidup parasit tersebut[tidak ada tanda titik](Skripsi A. 2014. Hal:23)

\section{Pembenaran}

1. ...bagaimana cara mencegah, menanggulangi dan mengobati penyakit Thelasia pada sapi di Distrik Klamono Kabupaten Sorong.

2. Pengembangan usaha peternakan dari kepentingan masyarakat pada umumnya di Distrik Klamono Kabupaten Sorong.

3. Thelasiosis merupakan suatu penyakit cacing mata yang disebabkan oleh Thelasia spp dan dapat menyerang berbagai jenis ternak. Thelasia spp yang benyak menyerang ternak sapi adalah ...

4. Diagnosa didasarkan atas ditemukan cacing Thelasia sp pada kantung konjungtif dengan jalan membuka kedua kelopak mata.

5. Pencegahan dilakukan penyemprotan secara teratur untuk membatasi faktor penyebab penyakit ini.

6. ....secara berkala setiap 3-4 bulan sekali guna membasmi cacing secara tuntas dan memutus siklus hidup parasit tersebut. 


\section{Kesalahan penggunaan tanda titik (Skripsi. O.G.2013)}

1. ...produksi ternak yang akan dihasilkan tidak akan sesuai dengan harapan, bahkan peternak bisa mengalami kerugian yang cukup besar(AAK, 1991)

(Skripsi B. 2013. Hal:1)

2. Sedangkan pertamabahan akibat penimbunan air bukanlah pertumbuhan murni(Anggorodi, 1984)

3. Pada siang hari sapi-sapi diikat dan ditambatkan di ladang, kebun, atau pekarangan yang rumputnya subur. Kemudian sore harinya sapi-sapi dimasukan ke dalam kandang.(Skripsi B. 2013. Hal:1)

4. Kegiatan produksi menunjukan kepada upaya pengubahan input atau sumber daya menjadi output berupa barang atau jasa (Herlambang, 2002)

\section{Pembenaran}

1. ...produksi ternak yang akan dihasilkan tidak akan sesuai dengan harapan, bahkan peternak bisa mengalami kerugian yang cukup besar. (AAK, 1991)

2. Sedangkan pertamabahan akibat penimbunan air bukanlah pertumbuhan murni. (Anggorodi, 1984)

3. Pada siang hari sapi-sapi diikat dan ditambatkan di ladang, kebun, atau pekarangan yang rumputnya subur, kemudian sore harinya sapi-sapi dimasukan ke dalam kandang.

4. Kegiatan produksi menunjukan kepada upaya pengubahan input atau sumber daya menjadi output berupa barang atau jasa(Herlambang, 2002)

\section{Kesalahan penggunaan tanda titik (Skripsis. A.B.2014)}

1. ......konsumsi protein hewani diperkirakan akan terus meningkat disamping peluang dan potensi pasar domestic, komoditas peternakan juga mempunyai potensi pasar ekspor (Elly, 2008). (Skripsi C. 2013. Hal:1)

2. Pendekatan proactive, dan partnership marketing sesuai dengan situasi pemasaran. Pendekatan proactive marketing berarti bahwa perusahan menghubungi pelanggan dari waktu ke waktu untuk mengetahui perkembangan pelayanan. Sedangkan partnership marketing berarti ...(Skripsi C. 2013. Hal:10)

\section{Pembenaran}

1. ......konsumsi protein hewani diperkirakan akan terus meningkat disamping peluang dan potensi pasar domestic, komoditas peternakan juga mempunyai potensi pasar ekspor (Elly, 2008).

2. Pendekatan proactive, dan partnership marketing sesuai dengan situasi pemasaran. Pendekatan proactive marketing berarti bahwa perusahan menghubungi pelanggan dari waktu ke waktu untuk mengetahui perkembangan pelayanan. Sedangkan partnership marketing berarti ... 


\section{Kesalahan penggunaan tanda titik (Skripsis. P.S. 2014)}

1. Pasokan daging kambing relative terbatas karena usaha peternakan kambing di Indonesia di dominasi oleh usaha rumah tangga dengan skala pemilikan 4-10 ekor (Murtidjo, 2001). (1)

2. Menurut Holmes et al. (1982) bobot badan seekor ternak dipengaruhi oleh factor bawaan dan factor lingkungan. (11)

3. Umur ternak mempengaruhi bobot badan dan bobot karkas dari seekor ternak, selanjutnya dikatakan oleh Williamson dan payne (1993)...(11)

\section{Pembenaran}

1. Pasokan daging kambing relative terbatas karena usaha peternakan kambing di Indonesia di dominasi oleh usaha rumah tangga dengan skala pemilikan 4-10 ekor. (Murtidjo, 2001).

2. Menurut Holmes et al (1982). Bobot badan seekor ternak dipengaruhi oleh factor bawaan dan factor lingkungan.

3. Umur ternak mempengaruhi bobot badan dan bobot karkas dari seekor ternak. Selanjutnya dikatakan oleh Williamson dan payne (1993)...

\section{Kesalahan penggunaan tanda koma (Skripsis. S.B. 2014)}

1. Penyakit parasit biasanya tidak mengakibatkan kematian hewan ternak, namun menyebabkan kerugian berupa penurunan kondisi badan dan daya produktivitas yang sangat besar. (skripsi A. 2014:01)

2. Bila keadaan ini dibiarkan dapat menyebabkan kekeruhan korneam keratitis, ulserasi pada kornea dan konjongtiva membengkak ....(skripsi A. 2014:02)

3. Thelaziosis pada sapi disebabkan oleh spesies Thelazia rhodesii, Thelazia guloso dan Thelazia skrjabini. (skripsi A. 2014. Hal. 02)

4. Data primer, yaitu data yang diperoleh dengan melakukan observasi yang pengamatan langsung terhadap usaha peternakan yang ada di lokasi penelitian dan yang diperoleh dari hasil kuisioner dan wawancara langsung dengan responden (skripsi A. 2014. Hal:15)

\section{Pembenaran}

1. Penyakit parasit biasanya tidak mengakibatkan kematian hewan ternak namun menyebabkan kerugian berupa penurunan kondisi badan dan daya produktivitas yang sangat besar.

2. Bila keadaan ini dibiarkan dapat menyebabkan kekeruhan korneam keratitis, ulserasi pada kornea, dan konjongtiva membengkak .... 
3. Thelaziosis pada sapi disebabkan oleh spesies thelazia rhodesii, thelazia guloso, dan thelazia skrjabini.

4. Data primer yaitu data yang diperoleh dengan melakukan observasi yang pengamatan langsung terhadap usaha peternakan yang ada di lokasi penelitian dan yang diperoleh dari hasil kuisioner dan wawancara langsung dengan responden

Kesalahan penggunaan tanda koma (Skripsis. O.G. 2013)

1. Di dalam kandang, sapi itu tidak diberi pakan tambahan lagi (Sugeng, 2005). (skripsi B. 2013. Hal:06)

2. pola kemitraan (PIR-NAK) merupakan kerjasama antara perusahan inti dengan peternak rakyat sebagai plasma dimana dalam kerjasama ini, seluruh kegiatan pra-produksi, produksi hingga pasca produksi dilakukan dengan kerjasama antara plasma dan inti (Daryanto, 2007) (skripsi B. 2013. Hal:09)

3. Penerimaan usaha peternakan sapi potong yang diperoleh dari penjumlahan antara jumlah sapi yang telah dijual, jumlah sapi yang telah dikonsumsi dan jumlah ternak sapi yang masih ada dijumlahkan dengan harga jual. (skripsi B. 2013. Hal:22)

4. Penelitian ini dilakukan pada wilayah Kelurahan Klamalu, dengan pertimbangan bahwa pada wilayah tersebut memiliki jumlah komunitas sapi potong terbesar, dibandingkan kelurahan lainnya. (skripsi B. 2013. Hal:28)

\section{Pembenaran}

1. Di dalam kandang sapi itu tidak diberi pakan tambahan lagi. (Sugeng, 2005).

2. Pola kemitraan (PIR-NAK) merupakan kerjasama antara perusahan inti dengan peternak rakyat sebagai plasma dimana dalam kerjasama ini, seluruh kegiatan pra-produksi, produksi hingga pasca produksi dilakukan dengan kerjasama antara plasma dan inti (Daryanto, 2007)

3. Penerimaan usaha peternakan sapi potong yang diperoleh dari penjumlahan antara jumlah sapi yang telah dijual, jumlah sapi yang telah dikonsumsi dan jumlah ternak sapi yang masih ada dijumlahkan dengan harga jual.

4. Penelitian ini dilakukan pada wilayah Kelurahan Klamaludengan pertimbangan bahwa pada wilayah tersebut memiliki jumlah komunitas sapi potong terbesar dibandingkan kelurahan lainnya.

\section{Kesalahan penggunaan tanda koma Skripsis. A.B.2014)}

1. Service bersifat sangat variable karena merupakan nonstandardised output artinya banyak variasi bentuk, kualitas dan jenis, tergantung pada siapa, kapan dan dimana serveice dihasilkan. (Skripsi C. 2014. Hal:05)

\section{Pembenaran}


1. Service bersifat sangat variable karena merupakan nonstandardised output artinya banyak variasi bentuk, kualitas dan jenis, tergantung pada siapa, kapan dan dimana service dihasilkan.

\section{Kesalahan penggunaan tanda koma (Skripsis. P.S. 2014)}

1. Sub sektor peternakan merupakan salah satu bagian yang tidak terpisahkan dari pembangunan sector pertanian, dimana peternakan merupakan suatu kegiatan usaha yang menrapkan prinsip-prinsip manajemen dan ke wirausahaan. (1)

2. Mulyana (1982), mengemukakan karena adanya modifikasi (penyesuaian bentuk luar tubuh terhadap lingkungan) maka sekarang kita mengenal dari bentuk yang kita lihat dan pelihara. (6)

\section{Pembenaran}

1. Sub sektor peternakan merupakan salah satu bagian yang tidak terpisahkan dari pembangunan sector pertanian, dimana peternakan merupakan suatu kegiatan usaha yang menrapkan prinsip-prinsip manajemen dan ke wirausahaan.

2. Mulyana (1982) mengemukakan karena adanya modifikasi (penyesuaian bentuk luar tubuh terhadap lingkungan) maka sekarang kita mengenal dari bentuk yang kita lihat dan pelihara.

\section{KESIMPULAN}

Berdasarkan hasil analisis datadapat disimpulkan bahwa hasil penelitian kesalahan ejaan pada beberapa Skripsi Mahasiswa Prodi Peternakan Fakultas Pertanian Universitas Victory Sorong diperoleh kesalahan sebanyak 255 kasus kesalahan, yang meliputi: (1) Kesalahan pemakaian pemakaian huruf, huruf kapital dan huruf miring berjumlah 105 kesalahan, (2) kesalahan penulisan kata yang meliputi kata dasar, kata turunan, kata ganti, kata depan, singkatan dan akronim berjumlah 88 (3) kesalahan pemakaian tanda baca berjumlah 62 kasus kesalahan.

\section{DAFTAR PUSTAKA}

Azwardi. 2008. Menulis ilmiah: Materi Kuliah Bahasa Indonesia Umum untuk Mahasiswa. Banda Aceh: Unsyiah.

Badan Pengembangan dan Pembinaan Bahasa Kementerian Pendidikan dan Kebudayaan . 2016. Pedoman Umum Ejaan Bahasa Indonesia. Jakarta : Kemendibud RI Depdiknas.2008. Kamus Besar Bahasa Indonesia Pusat Bahasa (Cetakan PertamaEdisi IV).Jakarta: PT Gramedia. 
Vol.1, No. 1, Juli 2021, hlm. 26-40

Hastuti PH, S. 2003. Sekitar Analisis Kesalahan Berbahasa Indonesia. Yogyakarta:Mitra Gama Widya.

Mustakim. 1994. Membina Kemampuan Berbahasa: Panduan ke arah Kemahiran Berbahasa. Jakarta: Gramedia Pustaka Utama.

Moleong, Lexy J. 2006. Metodologi Penelitian Kualitatif. Bandung: Rosda. 